\section{Proximal 10q trisomy: a new case with anal atresia}

EDITOR-Duplication of proximal segments of the long arm of chromosome 10 is rare and results in a pattern of malformations and dysmorphic features that are distinct from those of the more common distal 10q trisomy syndrome. To our knowledge, only nine patients with proximal 10q trisomy have been documented. Well defined clinical features of proximal $10 \mathrm{q}$ trisomy syndrome are growth and developmental retardation, ocular malformations like iris coloboma and retinal dysplasia, craniofacial dysmorphism, cardiac defects, and skeletal changes. ${ }^{1-9} \mathrm{We}$ describe anal atresia with fistula, coloboma of the iris, retinal dysplasia, developmental delay, and unusual facial features in a girl with de novo direct duplication of 10q11.222.3. In order to delineate the syndrome further, her phenotype at birth and on follow up at 8 months of age is also compared with the known cases.

Our proband is a Chinese girl, the second child born to a pair of non-consanguineous, healthy parents. She was born at term with a birth weight of $3000 \mathrm{~g}$ (50th centile) after an uneventful antenatal period. She was then ascertained because of multiple congenital anomalies including multiple capillary haemangiomata, bilateral micro-ophthalmia with colobomata of the irides, imperforate anus, and structural club feet. Further radiological contrast study confirmed anal atresia of low type, with an anovaginal fistula just above the anatomical anal verge. Detailed ophthalmological examination showed bilateral hypoplasia of the optic discs and fovea with general retinal pigmentary disturbance. Magnetic resonance imaging of the brain showed absence of myelination of the optic tract. Echocardiogram and renal ultrasound examination were normal.

After anoplasty on day 1, our patient enjoyed relatively good general health. Up to 8 months of age, her physical growth was between the 25th and 50th centile for body length, weight, and head circumference. However, developmental assessment showed that she was globally delayed with no visual response. Unusual craniofacial features included prominent forehead, divergent strabismus, deep set eyes with blepharophimosis, epicanthus, short philtrum, upturned nostrils, bow shaped mouth (fig 1), high arched palate, low set and flattened ears with thick helices and anthelices, and multiple capillary haemangiomata on the upper eyelids, left ear, and submandibular region. Neurological examination showed generalised hypertonia and brisk knee jerks.

Peripheral blood lymphocyte cultures were prepared for Giemsa banding analysis using standard techniques. ${ }^{10}$ Metaphase chromosomes were analysed by high resolution banding at the 550 to 850 band level. ${ }^{11}$ The karyotype is 46,XX,dup(10)(q11.21-q22.3) where one chromosome 10 contains an extra chromosomal segment, which is identified as a duplication of chromosome 10 from q11.21 to q22.3. Fig 2 shows the normal chromosome 10 (left) and the duplicated chromosome 10 (right). The origin of the extra segment was confirmed by fluorescence in situ hybridisation using a whole chromosome painting probe for chromosome 10 according to a standard protocol. ${ }^{12}$

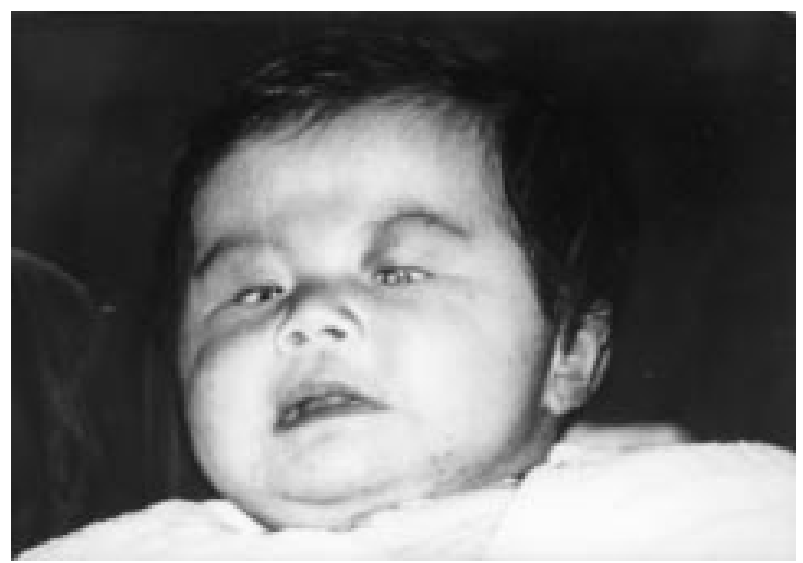

Figure 1 Facial appearance of the proband: prominent forehead, blepharophimosis, anteverted nostrils, short philtrum, bow shaped mouth, and capillary haemangiomata on the upper eyelids and left submandibular region.

Karyotypes on peripheral blood lymphocytes of both parents were normal.

Our patient has a de novo direct duplication of 10q11.2q22.3, which is evident by high resolution karyotyping and fluorescence in situ hybridisation using a whole chromosome painting probe of chromosome 10 . Serial duplication refers to the duplication of a chromosomal segment within the same chromosome, which has been well described in autosomes. It was suggested that it might arise from unequal crossing over or a spontaneous reciprocal translocation during meiosis in either parent, involving homologous chromosomes. ${ }^{1}$ Direct duplication describes the same orientation of the duplicated segment to the centromere as the original segment.

Duplication of the proximal long arm of chromosome 10 is rare and a distinct pattern of malformations has been established from the previously reported nine cases. The characteristic features of the present and reported cases are compared in table 1 . In summary, the present patient displayed the typical dysmorphic features as well as characteristic ocular and ophthalmological malformations of proximal $10 \mathrm{q}$ trisomy. On the other hand, she also had unique clinical features of anal atresia with anovaginal fistula and multiple capillary haemangiomata on the face and neck. Moreover, at 8 months old her physical growth was not retarded as in the previously described patients.

Our patient is distinctive in having anal malformation. It is possible but unlikely that the chromosomal rearrangement and the major malformation of imperforate anus occurred coincidentally given the relatively rare occurrence of both. Although it has never been reported in proximal 10q rearrangements, anal malformations like imperforate anus, ${ }^{13-15}$ anteriorly displaced anus, ${ }^{16}$ and "cloaca-like" appearance of an anterior anus and posterior urethra ${ }^{17}$ have been reported in cases of partial monosomy of distal 10q. In their report, Tsukuda et $a l^{13}$ reviewed cases with anogenital anomalies and partial monosomy of distal 10q with breakpoints at $10 \mathrm{q} 25$ and $10 \mathrm{q} 26$ and suggested that segment 10q25-26 might contain genes involved in rectal and anal development. Interestingly, our proband has anal atresia and duplication of a more proximal segment, 10q11.2-q22.3. To date, mapping of genes on the long arm of chromosome 10 does not yield any candidate specific for anorectal development. The RET proto-oncogene, which is mapped to 

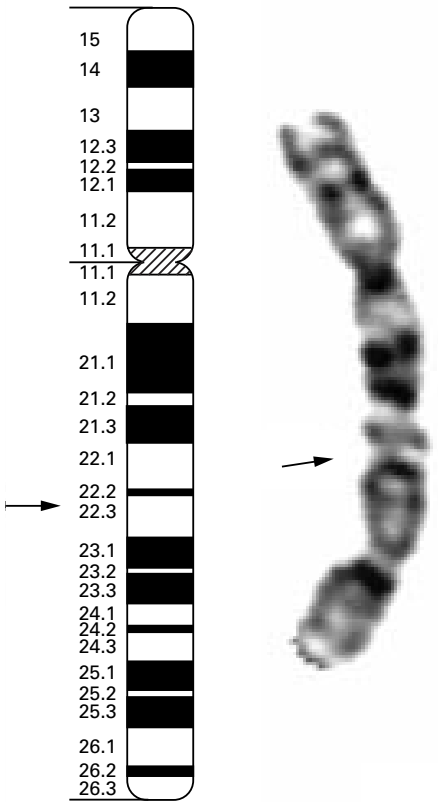

10
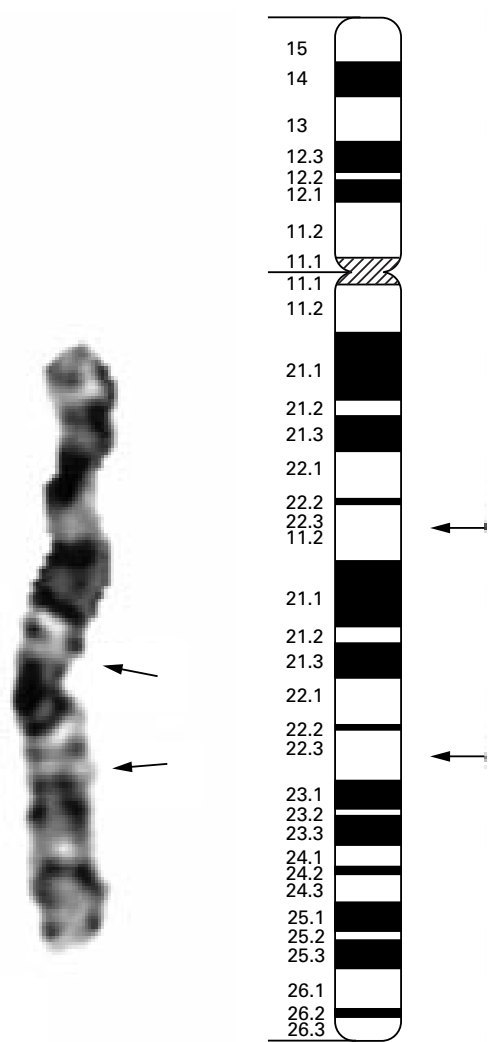

26.3

Figure 2 Normal chromosome 10 (left) and the abnormal chromosome 10 (right) showing the duplicated segment containing region 10q11.2 to q22.3.

$10 \mathrm{q} 11.2$, is associated with colonic agangliosis, ${ }^{18}$ which results in Hirschsprung's disease but not structural anal defect.

On the other hand, ocular and ophthalmological malformations are well known in trisomy distal $10 \mathrm{q}$ syndrome and encompass a broad spectrum. Frequently found ocular findings include hypertelorism, microphthalmia, and blepharoptosis $^{19}$ and an isolated case showed poor development of the anterior chamber. ${ }^{20}$ Ophthalmological findings are rarer in trisomy distal $10 \mathrm{q}$ and pallor or blurring of the optic discs have been described. ${ }^{20}{ }^{21}$ Our patient had microphthalmia, deep set eyes, iris coloboma, hypoplasia of the optic discs, pigmentary retinal dysplasia and absence of myelination of the optic tract. Her eye malformations were more extensive than other reported cases of partial $10 \mathrm{q}$ trisomy. Therefore, we emphasise that detailed and sophisticated ophthalmological assessment should be performed in all cases of trisomy 10q.

Table 1 Comparison of clinical features of patients with proximal trisomy $10 q$

\begin{tabular}{|c|c|c|c|c|c|c|c|c|c|}
\hline & Present case & Vogel et al ${ }^{l}$ & Fryns et al ${ }^{6}$ & $\begin{array}{l}\text { De Michelena } \\
\mathcal{E}^{\circ} \text { Campos }^{7}\end{array}$ & Aalfs et $a l^{8}$ & $\begin{array}{l}\text { Van } \\
\text { Buggenhout } \\
\text { et al }\end{array}$ & $\begin{array}{l}\text { Surana } \text { Park }^{2} \\
\end{array}$ & Koivisto et al $l^{3}$ & $\begin{array}{l}\text { Reinthaller et } \\
a l^{5}\end{array}$ \\
\hline Sex & $\mathrm{F}$ & $M$ & $\mathrm{~F}$ & $\mathrm{~F}$ & $\mathrm{~F}$ & $\mathrm{~F}$ & $M$ & $M$ & $M$ \\
\hline Age & $8 \mathrm{mth}$ & $7 \mathrm{y}$ & $16 \mathrm{y}$ & 2 y $8 \mathrm{mth}$ & 3 y 6 mth & 1 y 2 mth & $3 \mathrm{y}$ & $8.5 \mathrm{y}$ & $39 \mathrm{y}$ \\
\hline Growth retardation & - & + & + & + & + & - & + & + & + \\
\hline $\begin{array}{l}\text { Developmental delay } \\
\text { Craniofacial }\end{array}$ & + & + & + & + & + & + & + & + & + \\
\hline Microcephaly & - & + & + & + & + & + & + & + & + \\
\hline Prominent forehead & + & + & + & + & + & + & + & + & - \\
\hline Deep set eyes & + & + & + & + & + & + & ND & + & + \\
\hline Microphthalmia & + & - & + & + & - & - & ND & + & - \\
\hline Iris coloboma & + & - & + & - & - & - & ND & + & - \\
\hline Retinal dysplasia & + & - & + & ND & - & - & ND & + & + \\
\hline Upturned nose & + & - & + & + & + & + & + & - & + \\
\hline Bow shaped mouth & + & + & + & + & + & + & ND & + & + \\
\hline Micrognathia & + & + & + & + & + & + & ND & + & + \\
\hline Flat, thick ear helix & + & + & + & + & + & + & ND & ND & - \\
\hline $\begin{array}{l}\text { Capillary } \\
\text { haemangioma }\end{array}$ & + & ND & ND & ND & ND & ND & ND & ND & ND \\
\hline $\begin{array}{l}\text { Cardiac defects } \\
\text { Skeletal }\end{array}$ & - & - & - & ND & - & PDA+VSD & ND & PDA & ND \\
\hline Slender limbs & + & + & + & - & - & - & + & + & ND \\
\hline Hands/feet & Club feet & Club feet & $\begin{array}{l}\mathrm{R} \text { hand } \\
\text { polydactyly }\end{array}$ & ND & Club feet & ND & $\begin{array}{l}\text { Feet } \\
\text { syndactyly }\end{array}$ & ND & ND \\
\hline $\begin{array}{l}\text { Others } \\
\text { Anal atresia }\end{array}$ & + & - & - & - & - & - & - & - & - \\
\hline Muscle tone & Hypertonic & ND & ND & Hypertonic & Hypertonic & Hypotonic & ND & Hypotonia & Hypotonia \\
\hline Trisomic segment of 10q & $11.2-22.3$ & $11-22$ & $11.2-22$ & $11-22$ & $11.2-22.3$ & $11-22$ & $21-22$ & $21-22$ & $21-22$ \\
\hline
\end{tabular}

ND: not documented. 
In conclusion, we describe a patient with serial duplication of $10 \mathrm{q}(11.2-22.3)$, who displayed not only common features of the previously reported cases but also anal atresia, which was only reported in distal monosomy $10 \mathrm{q}$. Her ocular and optic pathway malformations were also well delineated and compared to other cases of trisomy $10 \mathrm{q}$. We expand the spectrum of anomalies associated with this rare chromosomal rearrangement in order to facilitate early clinical recognition and we believe that ongoing gene mapping will elucidate a better karyotype-phenotype correlation in the near future.

F W F LAM* W K CHAN* $S$ T S LAM* W P CHUt

N S KWONG+

${ }^{\star}$ Clinical Genetic Service, Department of Health, Hong Kong, China †Department of Paediatrics, Tuen Mun Hospital, Hong Kong, China

Correspondence to: Dr Lam, Clinical Genetic Service, 3/F, Cheung Sha Wan Jockey Club Clinic, 2 Kwong Lee Road, Sham Shui Po, Kowloon, Hong Kong, wflam@hingtekhong.com.hk

1 Vogel W, Back E, Imm W. Serial duplication of $10(\mathrm{q} 11 \rightarrow \mathrm{q} 22)$ in a patient with minor congenital malformations. Clin Genet 1978;13:159-63.

2 Surana RB, Park MY. Trisomy 10q due to de novo duplication of q21 and q22 bands. Am f Hum Genet 1980;32:90A.

3 Koivisto M, Herva R, Linna SL. Serial duplication of $10(\mathrm{q} 21 \rightarrow \mathrm{q} 22)$ in a mentally retarded boy with congenital malformations. Hum Genet $1981 ; 57$ : 224-5.

4 Taysi K, Yang V, Monaghan N, Berghaha N. Partial trisomy 10q in three unrelated patients. Ann Genet 1983;26:79-85.

5 Reinthaller A. Tandem duplication of $10(\mathrm{q} 21 \rightarrow \mathrm{q} 22)$ in a mentally deficient man. Clin Genet 1985;28:394-6.

6 Fryns JP, Kleczkowska A, Igodt-Ameye L, Van den Berghe H. Proxima duplication of the long arm of chromosome 10(10q11.2 $\rightarrow 10 \mathrm{q} 22)$ : a distinct clinical entity. Clin Genet 1987;22:61-5.
7 de Michelena MI, Campos PJ. A new case of proximal 10q partial trisomy. 7 Med Genet 1991;28:205-6.

8 Aalfs CM, Hoovers JMN, Nieste-Otter MA, Mannens MMAM, Hennekam RCM, Leschot NJ. Further delineation of the partial proximal trisomy 10q syndrome. F Med Genet 1995;32:968-71.

9 van Buggenhout G, Decock P, Fryns JP. A distinct phenotype associated with partial trisomy $10 \mathrm{q}$ due to proximal direct duplication $10 \mathrm{q} 11 \rightarrow \mathrm{q} 22.3$. Genet Couns 1996;7:53-9.

10 Seabright $M$. A rapid banding technique for human chromosomes. Lancet 1971;ii: 971 .

11 Yunis JJ. High resolution of human chromosomes. Science 1976;191:126870.

12 Lichter P, Ledbetter SA, Ledbetter DH, Ward DC. Fluorescence in situ hybridization with Alu and L1 polymerase chain reaction probes for rapid characterization of human chromosomes in hybrid cell lines. Proc Natl Acad Sci USA 1990; 87:6634-8.

13 Tsukuda T, Nagata I, Sawada H, Murakami J, Hanaki K, Urashioma H, Kaneda T, Shimizu N, Kaibara N, Kodama N, Ohzeki T, Shiraki K. Partial monosomy $10 \mathrm{q}$ and partial trisomy $9 \mathrm{q}$ with anal atresia due to maternal translocation: t(9;10)(q32;q26). Clin Genet 1996;50:220-2.

14 Wegner RD, Kunze J, Paust H . Monosomy 10 qter due to a balanced familial translocation: t(10;16)(q25;q24).Clin Genet 1981;19:130-3.

15 Wulfsberg EA, Weaver RP, Cunniff CM, Jones MC, Jones KL. Chromosome 10 qter deletion syndrome: a review and report of three new cases. $A m \mathcal{F}$ Med Genet 1989;32:364-7.

16 Brusnicky J, Van Heerden KMM, De Jong G, Cronjé AS, Retief AE. Severe mental retardation in six generations of a large South African family carrying a translocation t(6;10)9q27;q25.2). F Med Genet 1986;23:43545.

17 Lewandowski RC, Kukolich MK, Sears JW, Mankinen CB. Partial deletion 10q. Hum Genet 1978;42:339-43.

18 Edery P, Lyonnet S, Mulligan LM, Pelet A, Dow E, Abel L, Holder S, Nihoul-Fekete C, Ponder BAJ, Munnich A. Mutation of the RET proto-oncogene in Hirschsprung's disease. Nature 1994;367:378-80.

19 Neely K, Mets MB, Wong P, Szego K. Ocular findings in partial trisomy 10q syndrome. Am f Ophthalmol 1988;106:82-7.

20 Moreno-Fuenmayor H, Zackai EH, Mellman WJ, Aronson M. Familial partial trisomy of the long arm of chromosome 10(q24-26). Pediatrics 1975;56:756.

21 Laurent C. Trisomie 10 partielle par translocation familliale $\mathrm{t}(1 ; 10)(\mathrm{q} 44$; q22). Humangenetik 1973;18:321. 